\title{
Retirement And Estate Planning With An Emphasis On Individual Retirement Accounts
}

Johnny Fryar, Jr., Coastal Carolina University, USA Joe Warther, Coastal Carolina University, USA Todd Thibodeau, Coastal Carolina University, USA Meyer Drucker, Coastal Carolina University, USA

\begin{abstract}
Tax sheltering earned income for use in later years has become the cornerstone of many taxpayers' retirement plans since so many companies have dropped their defined benefit pension plans in order to remain competitive in today's international market place. Many taxpayers are utilizing Traditional IRAs, Roth IRAs and designated Roth accounts as important financial planning tools when the other plans are not readily available or no longer useful for their situations.
\end{abstract}

Keywords: Traditional IRA; Roth IRA; Stretch IRA; Tax Issues; and Retirement Plans

\section{INTRODUCTION}

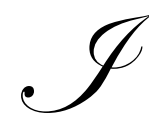

ndividuals making retirement plans must depend more on individual investment decisions than in the past 50 years. Many individuals are still relying on Social Security and corporate pensions almost exclusively to fund their retirement. This can be very dangerous for one's retirement planning based on present financial realities.

At the halfway mark of 2011 , the amount of under-funding in corporate pension plans totals $\$ 388$ billion. $^{2}$ According to Credit Suisse, the funding hole in US corporate pension plans is now larger than at the height of the financial crisis. ${ }^{2}$ Additionally, the percentage of companies in the private sector offering defined benefit pension plans has fallen from $40 \%$ in 1980 to $20 \%$ today. The uncertainty of Social Security and the decline of corporate pensions have placed added emphasis on defined contribution plans such as 401(k), 403(b), and 457 as well as Individual Retirement Accounts (IRAs).

One of the main vehicles for individual retirement planning has become the Individual Retirement Account (IRA). IRAs are the single largest component of the U.S. retirement market, holding $\$ 3.6$ trillion of assets at yearend 2008 (out of a total of $\$ 14$ trillion of retirement plan assets). ${ }^{3}$ The two main types of IRAs are:

(1) The Traditional IRA

(2) The Roth IRA

This paper will focus on the important features and differences of the different IRA plans and how they can be used in estate planning.

\section{THE TRADITIONAL IRA}

What is known as the Traditional IRA today came into effect on September 2, 1974 when President Ford signed into law the Employment Retirement Income Security Act (ERISA). ${ }^{4}$ The original purpose of the investment was to provide an option for employees without a company pension plan to save tax-deferred money for their 
retirement. The funds of this plan are contributed to the fund tax-free, the earnings on the plan are tax-free, and are not taxed until the funds are withdrawn from the plan.

Individuals who invest in the Traditional IRA are allowed to make tax-deferred contributions up to a certain amount each year. Individuals can make contributions into the Traditional IRA until they reach $701 \frac{1}{2}$ years old. At this point individuals are required to start withdrawing funds from the plan, unless they continue working. Traditional IRAs typically do not have limitations for contributions regarding an individual's income, with some exceptions (See Table 1 and Table 2). For example, someone who makes $\$ 30,000$ a year can potentially contribute the same amount as someone who makes $\$ 150,000$.

For the year 2011, the contribution limit is $\$ 5,000$ for those under the age of 50, and $\$ 6,000$ for those of age 50 and over. This increase is known as the "catch-up provision". This provision allows older investors to contribute more as their time to invest decreases. Contributions to the Traditional IRA depend on whether the individual or individual's spouse participate in an employer sponsored retirement plan and the individual's adjusted gross income (AGI). If the individual and their spouse do not participate in any sponsored retirement plan, the contributions are fully deductible, subject to the $\$ 5,000$ or $\$ 6,000$ limit. If an individual and their spouse participate in an employer sponsored retirement plan, the adjusted gross income level will determine how much of the contribution is tax deductible. For details, see Table 1. In cases where an individual does not participate in a sponsored retirement plan, but their spouse does, the amount of the contribution may be limited as well. For more details, see Table 2 .

Table 1: Deductions for Traditional IRA when participating in Employer Sponsored Retirement Plan - Adjusted gross income ${ }^{5}$

\begin{tabular}{|c|c|c|c|c|}
\hline Your tax filing status & Tax year & Full deduction & Partial deduction & No deduction \\
\hline Single/Head of Household & 2011 & Up to & $\$ 56,000-$ & Above \\
& & $\$ 56,000$ & $\$ 66,000$ & $\$ 66,000$ \\
\hline Married Filing Jointly & 2011 & Up to & $\$ 90,000-$ & Above \\
& & $\$ 90,000$ & $\$ 110,000$ & $\$ 110,000$ \\
\hline Married Filing Separately & 2011 & N/A & $\$ 0-\$ 10,000$ & Above \\
& & & & $\$ 10,000$ \\
\hline
\end{tabular}

Table 2: Traditional IRA Deductions with Spouse Participating in a Sponsored Retirement Plan - Combined Adjusted Gross Income ${ }^{5}$

\begin{tabular}{|c|c|c|c|}
\hline Tax year & Full deduction & Partial deduction & No deduction \\
\hline 2011 & Below $\$ 169,000$ & $\$ 169,000-\$ 179,000$ & $\$ 179,000$ and Above \\
\hline
\end{tabular}

Investors can start withdrawing their funds from a Traditional IRA as early as age $591 / 2$. Any withdrawals made before that age is subject to a $10 \%$ penalty, with a few exceptions. These exceptions include medical expenses above the $7.5 \%$ of AGI, higher educational expenses, and health insurance premiums. While distributions from the IRA can start as early as $591 / 2$, by age $701 / 2$, the individual is required to start taking distributions, whether it is monthly or lump sum. The IRS's Required Minimum Distribution (RMD) mandates these distributions.

\section{THE ROTH IRA}

The Roth IRA was created as part of the Tax Payer Relief Act of 1997, signed into law by President Clinton. It was named for Senator William V. Roth, Jr., the key sponsor of the bill. ${ }^{6}$ The purpose of creating the Roth IRA was to provide an alternative for investors to the Traditional IRA.

In order to be eligible to make contributions to a Roth IRA, the contributions must be income that is earned. Individuals must use income in which work was performed, like their wages or Schedule $\mathrm{C}$ income; however, investment and rental income does not count. The Roth IRA does have limitations with regard to income of less than $\$ 107,000$ for single individuals or head of household. A married couple filing jointly or a qualified widow(er) must have modified adjusted gross income of less than $\$ 169,000$, while married filing separately must have modified adjusted gross income of less than $\$ 10,000$ in order to make a full contribution. To make a penalty - free 
withdrawal from a Roth IRA before age 59 1/2, the individual must have owned their Roth IRA for five years or be a first-time home buyer up to the $\$ 10,000$ lifetime limit or be permanently disabled.

With a Roth IRA, individuals may make contributions that are not tax deductible up to a specified limit. The contribution limits are exactly the same as those previously outlined for the Traditional IRA. For tax year 2011, the limits are $\$ 5,000$ for persons under age 50 and \$6,000 for persons of age 50 and over. The reason for this additional $\$ 1,000$ is to enable the person to catch up on their retirement savings. ${ }^{7}$ Contributions to a Roth IRA may be made past age 70 1/2. In fact, there is no limitation on the age at which one makes contributions to a Roth IRA. One could still make contributions to a Roth IRA at age 80 if they so choose. Provided one spouse has compensation income, the other spouse is eligible to contribute to a Roth IRA if they file married filing jointly on their taxes. ${ }^{7}$

When taking distributions from a Roth IRA, the distribution is not taxed, which makes this type of IRA very attractive. Other IRAs require individuals to withdraw amounts each year at a certain age. Another benefit of the Roth IRA is that there is no age requirement on when an individual can start taking contributions from their account. The tax has already been paid on the amount invested in the IRA, so the money can remain in there for as long as desired. In addition, unlike other retirement plans, the Roth IRA does not require a minimum required distribution. The individual can decide to take a contribution at the age of 85 and at any amount without a late withdrawal fee charged to the individual by the IRS.

Table 3: Traditional IRA and Roth IRA Comparison ${ }^{8}$

\begin{tabular}{|l|c|c|}
\hline & Traditional IRA & Roth IRA \\
\hline Maximum Contributions Amount for 2011 & $\$ 5,000$ (under 50), $\$ 6,000$ (50 plus) & $\$ 5,000$ (under 50), $\$ 6,000$ (50 plus) \\
\hline & None & $\$ 107,000$ MAGI for Individuals, \\
Income Limitations (for full contributions) & & $\$ 169,000$ MAGI for married couples \\
\hline Tax-Deductible Contributions & Yes & No \\
\hline Taxable Distributions & Yes & None \\
\hline Contribution Age Limit & $701 / 2$ & No \\
\hline Required Minimum Distribution & Yes & 59 1/2 (some exceptions) \\
\hline Penalty-Free Distribution Age Limit & $591 / 2$ (some exceptions) & none \\
\hline Required Distribution Age & $701 / 2$ & \\
\hline
\end{tabular}

\section{ROLLING OVER AN IRA}

The term rollover is used to describe a nontaxable distribution from other tax deferred plans such as 401(k), 403(b), or 457, into an IRA account. It should be noted that if one rolls over funds from an employer-sponsored plan into an IRA, the funds typically cannot be rolled over into another employer-sponsored plan at a later date. The opening contribution, or rolled over funds, is not subject to a contribution limit. However, annual contributions are subject to the same maximum contribution limit as with Traditional IRAs.

Funds from other plans such as 401(k), 403(b), or 457 cannot be rolled over directly into a Roth IRA. However, once they have been rolled over into an IRA, the Traditional IRA can later be converted into a Roth IRA.

When an indirect roll over is performed, the IRS allows 60 days for this transaction to occur or else the withdrawal is taxable. The IRS only allows this type of rollover to occur once per year. The most attractive method to transfer money from one retirement account to another is called the direct rollover. This means that the funds go directly from one bank or brokerage firm to another without the owner touching the money en route. ${ }^{9}$ The reason for this method being more attractive than the rollover is because not only is it tax-free and safe, but an individual is allowed as many direct rollovers as he/she wants compared to one indirect rollover per year. 


\section{BENEFITS OF ROLLING OVER TO AN IRA}

A significant advantage of utilizing an IRA rather than a company retirement account is its flexibility in the owner that can keep the money growing after death for his or her beneficiaries. A 403(b) does not allow the money to keep growing. It often requires cash-outs after a certain period of time. An IRA beneficiary can be any individual or multiple individuals and the IRA can be split into various accounts. ${ }^{9}$ IRAs allow an individual to invest in many different types of investments such as annuities, which is an option that most retirement plans do not offer. Annuities offer guaranteed death benefits amongst other living benefits, which is a great option for individuals. For example, say a person died in 2008 while the market was significantly dropping; the guaranteed death benefit would be paid out to the beneficiaries at the higher pre-determined value. ${ }^{9}$

In many cases, company retirement accounts are handled by employees who work in Human Resources. A benefit to rolling over to an IRA is that it's often handled by retirement plan professionals who are earning commission. ${ }^{9}$ Therefore, not only do retirement plan professionals know what they are talking about, but they also want their clients to save as much money as possible. Once an individual retires and is an ex-employee, that person is probably receiving little if any attention from his/her prior employer. With an IRA, the owner of that account is not only receiving professional attention, but more of it. Many changes can still be made to the account based on risk and one's specific retirement situation. The owner of an IRA has more control of the account than a company account. Although there are benefits to rolling over to an IRA, sometimes it is not allowed or there are certain requirements that must be met in order to rollover from one account to another (See Table 4).

Table 4: Rollover Chart $^{10}$

\begin{tabular}{|c|c|c|c|c|c|c|c|}
\hline & \multicolumn{6}{|c|}{ Roll To } \\
\hline & & Roth IRA & Traditional IRA & 457 & 401(k) & 403(b) & Designated Roth Account \\
\hline \multirow{6}{*}{$\begin{array}{l}\text { Roll } \\
\text { From }\end{array}$} & Roth IRA & YES & $\mathrm{NO}$ & $\mathrm{NO}$ & $\mathrm{NO}$ & $\mathrm{NO}$ & $\mathrm{NO}$ \\
\hline & Traditional IRA & YES $^{\mathrm{a}}$ & YES & YES & YES & YES & $\mathrm{NO}$ \\
\hline & 457 & YES $^{\mathrm{a}}$ & YES & YES & YES & YES & $\mathrm{YES}^{\mathrm{a}, \mathrm{c}}$ after $12 / 31 / 10$ \\
\hline & 401(k) & YES $^{\mathrm{a}}$ & YES & YES $^{\mathrm{b}}$ & YES & YES & YES, a, c after $9 / 27 / 10$ \\
\hline & 403(b) & YES $^{\mathrm{a}}$ & YES & YES $^{b}$ & YES & YES & YES, ${ }^{\text {a, c }}$ after $9 / 27 / 10$ \\
\hline & $\begin{array}{l}\text { Designated Roth } \\
\text { Account }\end{array}$ & YES & NO & NO & NO & NO & $\begin{array}{l}\text { YES, if a direct trustee to } \\
\text { trustee transfer }\end{array}$ \\
\hline
\end{tabular}

${ }^{\mathrm{a}}$ Must include in income; ${ }^{\mathrm{b}}$ Must have separate accounts; ${ }^{\mathrm{c}}$ Must be an in-plan rollover

\section{COMPARISON OF TRADITIONAL AND ROTH IRA}

The key difference between the Traditional IRA and the Roth IRA is the impact of income taxes. Contributions to Traditional IRAs are tax-deferred. However, all distributions from Traditional IRAs after age 59 1/2 are taxed as ordinary income. Contributions to Roth IRAs are not tax-deferred, but the distributions from them after age $591 / 2$ are tax free. To simplify, an individual pays taxes later on all distributions taken from a Traditional IRA, while an individual pays taxes when earned on all contributions made to a Roth IRA. How does one determine which is the best choice? The answer is in the tax bracket one is in now versus the tax bracket they expect to be in the future. For example, see Table 5 for a comparison of retirement dollars available to an investor at retirement with each plan. Unless there is a dramatic decrease in the tax bracket one expects to be in during their retirement years, the investor would have more money available for their retirement from investing in a Roth IRA. The example given in Table 5 assumes a modest decrease in the federal income tax rate for the retiree from $28 \%$ to $25 \%$. Investors who contribute $\$ 4,000$ per year in a Roth IRA for 30 years would have $4.6 \%$ more funds available than if they had invested in a Traditional IRA within the parameters given in Table 5. See Table 6 to see the effects of the tax rate staying the same and Table 7 to see the effects of an increase in the tax rate. 
Table 5: Minor Decrease in Tax Rate ${ }^{11}$

\begin{tabular}{|l|c|}
\hline Annual Contribution & $\$ 4000$ \\
\hline Contribution Years & 30 \\
\hline Assumed Rate of Return & $6 \%$ \\
\hline Current Federal Income Tax Rate & $28 \%$ \\
\hline Future Federal Income Tax Rate & $25 \%$ \\
\hline Retirement Age & 67 \\
\hline Roth IRA Account Total & $\$ 335,207$ \\
\hline Traditional IRA Account Total after Taxes & $\$ 320,549$ \\
\hline
\end{tabular}

Table 6: No Change in Tax Rate ${ }^{11}$

\begin{tabular}{|l|c|}
\hline Annual Contribution & $\$ 4000$ \\
\hline Contribution Years & 30 \\
\hline Assumed Rate of Return & $6 \%$ \\
\hline Current Federal Income Tax Rate & $25 \%$ \\
\hline Future Federal Income Tax Rate & $25 \%$ \\
\hline Retirement Age & 67 \\
\hline Roth IRA Account Total & $\$ 335,207$ \\
\hline Traditional IRA Account Total after Taxes & $\$ 315,157$ \\
\hline
\end{tabular}

Table 7: Increase in Tax Rate I1 $^{11}$

\begin{tabular}{|l|c|}
\hline Annual Contribution & $\$ 4000$ \\
\hline Contribution Years & 30 \\
\hline Assumed Rate of Return & $6 \%$ \\
\hline Current Federal Income Tax Rate & $25 \%$ \\
\hline Future Federal Income Tax Rate & $28 \%$ \\
\hline Retirement Age & 67 \\
\hline Roth IRA Account Total & $\$ 335,207$ \\
\hline Traditional IRA Account Total after Taxes & $\$ 305,101$ \\
\hline
\end{tabular}

If planned properly, a Traditional IRA can provide many advantages for retirement. As noted earlier, Traditional IRAs allow for deductions on contributions and tax-free earnings. Tax savings and tax-free earnings can help in creating substantial wealth. One example is if an individual expects to be in a lower tax bracket in their retirement as opposed to their current bracket. If an individual in the $28 \%$ tax bracket contributes $\$ 5,000$ to their Traditional IRA, not only are they gaining value for their retirement, but also they are decreasing their current tax liability by $\$ 1,400(5000 \times$.28). If the individual is in $15 \%$ tax bracket in their retirement, when the funds are withdrawn, their tax liability will be $\$ 750$ on that particular $\$ 5,000$. While the $\$ 650$ in savings yearly may not seem substantial, over a 40-year period, the savings would accumulate to $\$ 26,000$.

When looking at tax brackets, it is only beneficial to use the Traditional IRA instead of the Roth IRA when an individual expects to be in a substantially lower tax bracket in the future. This can easily happen if an individual does not have pension income.

Table 8: Major Decrease in Tax Rate ${ }^{11}$

\begin{tabular}{|l|c|}
\hline Annual Contribution & $\$ 4000$ \\
\hline Contribution Years & 30 \\
\hline Assumed Rate of Return & $6 \%$ \\
\hline Current Federal Income Tax Rate & $28 \%$ \\
\hline Future Federal Income Tax Rate & $15 \%$ \\
\hline Retirement Age & 67 \\
\hline Roth IRA Account Total & $\$ 335,207$ \\
\hline Traditional IRA Account Total after Taxes & $\$ 354,070$ \\
\hline
\end{tabular}


Another difference between the Traditional IRA and the Roth IRA is the distribution requirement. Specifically, there is a required minimum distribution for Traditional IRAs that varies by the age of the retiree. The minimum required distribution (MRD) can be calculated by dividing the owner's account balance by the appropriate MRD withdrawal factor for the account owner's age. For example, a 75 year old with an account balance of $\$ 300,000$ would divide their balance by 22.9 and find that their MRD is $\$ 13,100.44$. By contrast, there is no required minimum distribution for a Roth IRA. The distribution requirement can also be a factor in determining which IRA is the best choice. Estate planning is related to the distribution requirement factor. The main benefit with regard to estate planning with Roth IRAs is gained when the spouse of the Roth account owner is listed as the sole beneficiary. The spouse of the deceased has the option of delaying distributions until the decedent would have reached $701 / 2$ or he/she may treat the Roth IRA as his/her own Roth IRA and have no distribution requirement.

\section{CONVERSION OF TRADITIONAL TO ROTH IRA}

In the past, Traditional IRAs may be converted into Roth IRAs with some limitations. Prior to 2010, in order to be eligible for conversion of a Traditional IRA into a Roth IRA the investor must have modified adjusted gross income of $\$ 100,000$ or less. Also, married couples filing separately are not eligible. The key point to be made with regard to the conversion of a Traditional IRA into a Roth IRA is that the account owner must pay income taxes on the amount converted. If the account owner is under age $591 / 2$, funds from outside the account must be used to pay the income taxes due from the conversion or pay a $10 \%$ tax penalty.

The question becomes, why would someone convert their IRA now and be subject to tax? One primary focus is on the expected tax rate upon retirement. If an individual expects to be in the same tax bracket in the future or in a higher tax bracket, converting to a Roth IRA makes sense because the distributions are tax-free. If the individual expects to be in a significantly lower tax bracket in the future, then it makes sense not to make the conversion. Table 9 outlines the advantages and disadvantages of conversion.

Table 9: Advantage (Disadvantage) per $\$ 1,000$ of Conversion

$(\text { Current Tax Rate }=25 \% \text {, Average Annual Rate of Return }=6 \%)^{12}$

\begin{tabular}{|l|c|c|c|c|}
\hline \multirow{2}{*}{ Future Tax Rate } & \multicolumn{4}{|c|}{ Time Horizon (years) } \\
\cline { 2 - 5 } & $\mathbf{5}$ & $\mathbf{1 0}$ & $\mathbf{1 5}$ & $\mathbf{2 0}$ \\
\hline $35 \%$ & $\$ 149$ & $\$ 216$ & $\$ 308$ & $\$ 435$ \\
\hline $25 \%$ & $\$ 15$ & $\$ 37$ & $\$ 69$ & $\$ 115$ \\
\hline $15 \%$ & $(\$ 118)$ & $(\$ 142)$ & $(\$ 171)$ & $(\$ 206)$ \\
\hline
\end{tabular}

If the account owner expects to be in a slightly lower tax bracket during their retirement years, it would also be wise for them to convert to a Roth IRA. See Table 10 for a comparison of funds available after retirement before and after conversion from a Traditional IRA to a Roth IRA.

Table 10: Retirement Funds Before and After Conversion from Traditional to Roth ${ }^{13}$

\begin{tabular}{|l|c|c|}
\hline Current IRA Balance & $\$ 20,000$ & $\$ 75,000$ \\
\hline Source of Taxes Due on Conversion & Outside the IRA & Outside the IRA \\
\hline Amount of Tax Due at Conversion & $\$ 5,600$ & $\$ 4,000$ \\
\hline Total Annual Contributions & $\$ 4,000$ & 30 \\
\hline Years Until Retirement & 30 & 25 \\
\hline Years to Make Withdrawals & 25 & $6 \%$ \\
\hline Investment Rate of Return & $6 \%$ & $28 \%$ \\
\hline Tax Bracket Pre-Retirement & $28 \%$ & $\$ 51,678$ \\
\hline Tax Bracket During Retirement & $25 \%$ & $\$ 56,528$ \\
\hline $\begin{array}{l}\text { Annual Withdrawals Available During } \\
\text { Retirement from Traditional IRA }\end{array}$ & $\$ 30,659$ & \\
\hline $\begin{array}{l}\text { Annual Withdrawals Available During } \\
\text { Retirement from Roth IRA }\end{array}$ & $\$ 33,215$ & \\
\hline
\end{tabular}




\section{EMPLOYER RETIREMENT PLANS}

The most popular employer retirement plans are now under 401(k); often with a company match. These plans allow an employee to defer from his/her paycheck. Similar to a Traditional IRA, the money in this account is not taxed until taken out. The reason for this is because these plans are both simple and flexible for employers. ${ }^{16}$ There is a variety of options for employers when choosing between different types of 401(k) plans and the employers can make them as simple or complex as desired.

Individuals may choose to have an IRA retirement account as well as a 401(k) account. A 401(k) is beneficial when it comes to contributions. The contributions are larger and more flexible. Annual contributions can be as high as $\$ 16,500$ and once an employee reaches the age of 50, that employee qualifies for an additional "catch up" annual contribution of $\$ 5.500 .^{16}$

A Simple 401(k) retirement plan is also an option for employers who wish to cut administrative costs. A higher flexibility given to employees under the 401(k) plan adds more administrative work for the employer, but with the Simple 401(k) plan administrative costs are much less. This plan is becoming more popular over the years because it's a straight forward retirement plan. It does have its pitfalls, like not being able to utilize other retirement plans. If the employee has a Simple 401(k) account, that employee is not allowed to have his/her own individual retirement account, or any retirement account for that matter. Another con to this plan is the lower contribution limits compared to the typical 401(k) plan. Although it does have its cons, a large pro for many companies is the ease and low-cost that the Simple 401(k) plan has to offer.

Table 11: Contribution Limit Comparison

\begin{tabular}{|l|c|c|c|}
\hline & IRA & $\mathbf{4 0 1}(\mathbf{k})$ & SIMPLE 401(k) \\
\hline Ages 49 and Under & 5,000 & 16,500 & 11,500 \\
\hline Ages 50 and Over & 6,000 & 22,000 & 14,000 \\
\hline
\end{tabular}

\section{DESIGNATED ROTH ACCOUNTS}

There are separate Roth accounts that employers sometimes offer their employees, called designated Roth accounts. These accounts are the best of both worlds. The account allows the high contributions of a 401(k) account, but also if qualified allow tax-free distributions of a Roth IRA. These accounts offer the opportunity to make after-tax salary deferral contributions to a 401(k), 403(b), and a $457 .{ }^{14}$ Contributions are limited to $\$ 16,500$ and $\$ 22,000$ if 50 years of age or older. Employees are allowed to make contributions to these plans and traditional pre-tax accounts within the same year. As long as the contribution stays within the limits, an employee may allocate his/her contributions to the plans in any proportion desired. There are many benefits of utilizing a designated Roth account compared to the Roth IRA.

Compared to a Roth IRA, designated Roth accounts: ${ }^{14}$

- Offer larger annual contribution limits than Roth IRAs,

- $\quad$ Are not subject to the modified gross income limitations that restrict some individuals from contributing to Roth IRAs, and

- Allow participants to keep their Roth and pre-tax savings within a single plan.

\section{STRETCHING IRA DISTRIBUTIONS}

One way to help build considerable wealth for an individual and their family in later generations is to "stretch" the IRA. The concept of "stretching" the IRA is to keep the inherited account growing tax-deferred as long as possible. This process is easy for both kinds of IRAs. To "stretch" the IRA, simply make sure that it has designated beneficiaries. The IRS declared that if you have a designated beneficiary on your retirement account, you're guaranteed the stretch option. This means that your named beneficiary can "stretch" his or her post death 
RMDs over his or her life expectancy according to the IRS Single Life Expectancy Table. The IRS does not set a dollar limit on how much the "stretch" can grow to, just a limit on when it must be withdrawn. ${ }^{9}$ In determining the beneficiaries, make sure to name a primary and contingent beneficiary. Contingent beneficiaries make sure that if something happens to the primary, the IRA account could still be stretched.

Failure to name beneficiaries can result in substantial tax liabilities and remove the option of "stretching" the IRA. In this case, the estate then becomes the beneficiary, and the IRA is then included in the gross estate and can be subject to immediate tax. Also, it is important to keep the IRA out of the individual's will. Fact is that most property passes outside of the will. When someone inherits through a will, the estate is the beneficiary. It makes no difference if the person receives the IRA through the estate. The estate is still the beneficiary on the date that the designated beneficiary is determined. ${ }^{9}$ Most property passes by the operation of the law and trumps any conflicting provision in the will. This is true for property that is passed by beneficiary designation, and an IRA is one example of this. They are assigned designations and are transferred according to the designation beneficiary form, not the will. The form overrides the will. So, if the IRA is one of the larger assets in the estate, then the beneficiary form is essential to make sure that the IRA has the opportunity to be stretched. ${ }^{9}$

\section{CONCLUSION}

The strategies individuals take with regard to IRA accounts vary, one thing is certain; a uniformed approach cannot be taken. A strategy that is correct for one person may not be right for another person. Today's business and political climates dictate that individuals learn the different facets of these accounts and start investing for their retirement if they have not already done so. For the most part, it's beneficial to rollover from a company retirement account into an IRA. The main reasons are due to the fact that the money keeps growing to the beneficiary after death and IRAs enable an individual to invest the money in a variety of investments. Now the question becomes, which IRA is more beneficial for your specific retirement situation?

Who should invest in a Roth IRA? While there are some grey areas, Roth IRA accounts will provide those individuals with more retirement money after taxes and give them greater flexibility with regard to using the money. Likewise, those individuals who do not exceed the income limitations previously outlined for conversions from Traditional IRAs to Roth IRAs should consider converting part of their IRA to a Roth IRA. Also, employees should look into designated Roth accounts if they are offered by the employer, which are separate accounts similar to a Roth IRA, but have a higher contribution limit.

Who should invest in a Traditional IRA? Traditional IRAs make sense for individuals who are in high tax brackets now, but expect to be in significantly lower tax brackets in the future. However, the deductions may be limited depending on the income of the individual.

Finally, if planned properly, distributions from the IRA can be stretched for generations. To ensure this, make sure that the IRA has a designated beneficiary and contingent beneficiaries on the beneficiary form, separate from the will. IRAs without beneficiaries are considered to be part of the estate, which then become taxable. Anything distributed by the will is considered to be part of the estate as well, and the tax benefits do not transfer.

\section{AUTHOR INFORMATION}

Johnny Fryar, Jr. is a 2002 graduate from The Citadel and a local financial advisor. In 2008 Johnny returned to school at Coastal Carolina University to obtain the prerequisites to become a CPA. He is the owner of a financial planning firm in Myrtle Beach and does consulting for Parker Hunter Skipper, CPA. E-mail: Johnny@PHSCPAs.com

Joe Warther is an instructor in Accounting at Coastal Carolina University. He is a CPA and also holds a Masters in Taxation from the University of Akron. Joe has spent most of his career working in Management Accounting. E-mail: JWather@Coastal.edu 
Todd Thibodeau graduated from Coastal Carolina University in May, 2010 with a BSBA, Accounting. He is currently a graduate student working toward a Master of Accountancy at Coastal Carolina University and studying for the CPA exam. Upon completion of his Masters in December of 2011, he will start his career as a Staff Accountant at Clifton Larson Allen LLP in Orlando, FL. E-mail: thibodeau.todd@gmail.com

Meyer Drucker is a Distinguished Professor Emeritus of the University of South Carolina at Spartanburg. He is a CPA and has an LLM in Taxation from Emory University, along with a JD from University of South Carolina. He recently retired from Coastal Carolina University after over 45 years of college teaching, where he taught taxation in both the undergraduate and graduate programs for the past 5 years. E-mail: meydrucker@aol.com. Corresponding author.

\section{REFERENCES}

1. Social Security Reform Center (2011). Social Security's Problem. Retrieved September 30, 2011, from: http://www.socialsecurityreform.org/problem/index.cfm

2. McCrum, Dan (2011). "Gap in US pension plans hits \$388bn" The Financial Times. Retrieved November 7, 2011, from: http://www.ft.com/intl/cms/s/0/1adc855a-d567-11e0-bd7e00144feab49a.html\#axzz1diapA8e1

3. Investment Company Institute (2009). Most Individual Retirement Account Assets Are Held in Traditional IRA Accounts. Retrieved November 10, 2011 from: http://www.ici.org/policy/retirement/retirement/09 news_retire market

4. About.com (2011). IRA 101- Traditional IRAs. Retrieved October 4, 2011, from: http://www.retireplan.about.com/od/rothtradtionaliras/a/IRA_101_trad_p.htm

5. $\quad$ State Farm Insurance (2011). Traditional IRA. Retrieved March 30, 2011, from: http://www.statefarm.com/learning/life_stages/retire/trad.asp

6. $\quad$ About.com (2011). IRA 101- Roth IRAs. Retrieved May 27, 2011, from: http://www.retireplan.about.com/od/rothtradtionaliras/a/IRA_101_roth_p.htm

7. Rothira.com (2011). Frequently Asked Questions. Retrieved April 6, 2011, from: http://www.rothira.com

8. Publication 590 (2011). Individual Retirement Arrangements (IRAs). Retrieved October 10, 2011, from: http://www.irs.gov/publications/p590/ar01.html

9. Slott, E (2007). The Retirement Savings Time Bomb... and how to defuse it. New York, New York: Penguin Group.

10. Irs.gov (2011). Rollover Chart. Retrieved May 23, 2011, from: http://www.irs.gov/pub/irstege/rollover_chart.pdf

11. State Farm Insurance (2011). Traditional vs. Roth IRA Calculator. Retrieved April 4, 2011, from: http://online2.statefarm.com/SFCalculators/execute.do?nextPage=TradRothIRACalculator

12. Charles Schwab \& Co., Inc (2009). 2010 Roth Conversion: Look Before You Leap. Retrieved April 29, 2011, from: http://www.schwab.com/public/schwab/research_strategies/market_insight/retirement_strategies/planning/ 2010 roth conversion look before you leap.html

13. Money Chimp (2011). Roth IRA Calculator. Retrieved September 25, 2011, from: http://www.moneychimp.com/articles/rothira/rothcalc.htm

14. Irs.gov. (2011) Designated Roth Accounts - Contributing to a Designated Roth Account. Retrieved April 10, 2011, from: http://www.irs.gov/retirement/article/0,,id=232327,00.html

15. Irs.gov (2011). Top Ten Differences Between a Roth IRA and a Designated Roth Account. Retrieved April 23, 2011, from: http://www.irs.gov/pub/irs-tege/roth differences.pdf

16. Irs.gov (2011). Choosing a Retirement Plan: 401(k) Plan. Retrieved October 10, 2011 from: http://www.irs.gov/retirement/article/0,,id=108942,00.html 


\section{NOTES}

